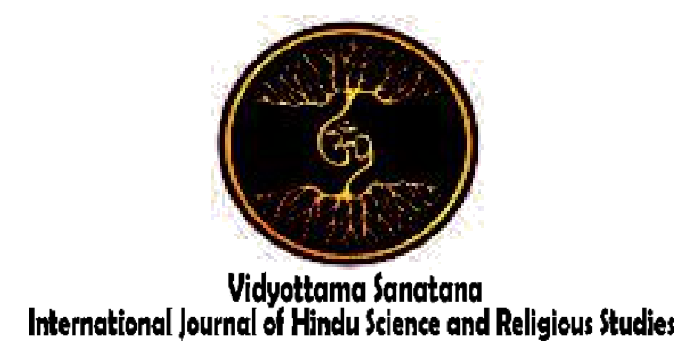

Vol. V No. 1 June 2021

\title{
COVID-19 AND PERCEPTIONS OF RELIGIOUS LEADERS; HINDU AND CONFUCIAN VIEWS OF EAST JAVA
}

\author{
By: \\ M.Thoriqul Huda \\ Institut Agama Islam Negeri (IAIN) Kediri \\ E-mail: huda@iainkediri.ac.id
}

Received: April 28, 2021

Accepted: Juni 30, 2021

Published: June 30, 2021

\begin{abstract}
The Covid-19 pandemic is a virus outbreak that has infested almost all countries in the world, its impact is felt in various fields, economic, social, cultural, political and religious. This study attempts to see more fully the opinions of religious leaders and Confucian and Hindu youths on the existence of Covid-19, by using a qualitative approach and interview techniques as a model for extracting data in the field. From the results of the study that has been carried out there are several things that can be concluded, firstly that both Confucian and Hindu religious figures and youths believe that Coovid-19 is a real thing that must be watched out together, secondly, in connection with the existence of Covid-19, it is necessary to jointly- the same to implement the health protocol rules that have been established by the government, third, theologically that in Hinduism a pandemic condition like this could happen if Tri Hita Karana does not work well
\end{abstract}

Keywords: Covid-19, Perceptions of People, Confucians and Hindus 


\section{INTRODUCTION}

At the end of 2019, the world was shocked by the discovery of a pneumonia case whose etiology was not clearly known, originating from Wuhan, China ${ }^{1}$. On January 7, 2020, China announced that pneumonia was a new virus ${ }^{2}$, the statement "urgent notice on the treatment of pneumonia of unknown cause" was issued by the Wuhan Municipal Health Committee ${ }^{3}$. The World Health Organization (WHO) has designated the outbreak caused by the corona virus as a global pandemic that has spread throughout the world on March 11, $2020^{4}$.

The spread of this virus is fast, both transmitted through humans and animals, this virus will directly attack the human respiratory tract with initial symptoms in the form of flu to acute respiratory syndrome (SARS), easily transmitted through respiratory droplets coughing or sneezing ${ }^{5}$. Seeing how easily this virus spreads, so in a short time, to be precise at the beginning of 2020 its spread has reached Indonesia, but there are still many people who still underestimate this virus.

Launching from the results of research at the University of Cambridge, which collected sample data from each

\footnotetext{
${ }^{1}$ Moulahoum, H., Ghorbanizamani, F., Zihnioglu, F., Turhan, K., \& Timur, S. How should diagnostic kits development adapt quickly in COVID 19-like pandemic models? Pros and cons of sensory platforms used in COVID-19 sensing. Talanta, 2021, 222.

${ }^{2}$ Loey, M., Manogaran, G., Taha, M. H. N., \& Khalifa, N. E. M. A hybrid deep transfer learning model with machine learning methods for face mask detection in the era of the COVID-19 pandemic. Measurement: 2021, 167

${ }^{3}$ Hanoatubun, "Dampak Covid-19 Terhadap Perekonomian Indonesia", Journal of Education, Psychology and Counseling, 2(1), 2020, 146-153.

${ }^{4}$ Baig, A. M. Updates on What ACS Reported: Emerging Evidences of COVID-19 with Nervous System Involvement. ACS Chemical Neuroscience, 11(9), 2021, 1204-1205.

${ }^{5}$ Ren L-L, Wang Y-M, Wu Z-Q, Xiang Z-C, Guo L, $\mathrm{Xu} \mathrm{T}$, Identification of a novel coronavirus causing severe pneumonia in human: a descriptive study. Chin Med J. 2020
}

country, that in several countries conspiracy theories over the existence of Covid-19 have taken root in society, the claim that Covid-19 was engineered by the Wuhan laboratory was trusted by $22-23 \%$ of respondents in the US and The UK, $22 \%$ of the people of Mexico and $18 \%$ of the Irish people also believe that Covid-19 is a conspiracy for global vaccine sales.

On September 7-14, 2020, the Central Statistics Agency (BPS) conducted a public opinion poll, the result was that $17 \%$ of Indonesians or 44.9 million people felt immune to exposure to the Covid-19 virus. Of the $17 \%$, there are $29.18 \%$ people in Maluku province, $27 \%$ people in North Sulawesi province, $25 \%$ people from East Nusa Tenggara, 22\% people in Southeast Sulawesi and $22.48 \%$ people in Central Sulawesi province ${ }^{6}$.

Even the results of a survey by the Spektrum Politika Institute (SPI) Research and Consultant Institute which was carried out on a period of 10-15 September 2020, revealed that $39.9 \%$ of the people of West Sumatra consider that Covid-19 is a global conspiracy, or a Western conspiracy to profit from sales of vaccines. The SPI further explained that the real impact of this perception is the neglect of the people of West Sumatra towards health protocols that the Government is diligently socializing.

The perception of feeling immune to the existence of the Covid-19 virus or considering this as a conspiracy, has actually had an impact on the low adherence of the community to health protocols, people have become ignorant of wearing masks, maintaining physical distance and washing their hands ${ }^{7}$. Even further, they are at risk of contracting the Covid-19 virus without any symptoms so that it has the potential to infect other people, this can create a massive explosion of Covid-19 patients.

\footnotetext{
${ }^{6}$ Badan Pusat Statistik (BPS).

${ }^{7}$ Hadiwardoyo, "Kerugian Ekonomi Nasional Akibat Pandemi Covid-19", Journal of Business \& Entrepreneurship, 2(2), 2020, 83-92
} 
Perception is very important in shaping individual behavior and the environment, Sondang P. Siagian divides the emergence of perceptions into several factors, including self-factors, target factors and situation factors ${ }^{8}$. Of these several factors, the self-factor becomes very important in determining the perception of what is gained from sensing, because in the process the formation of perceptions is very much determined by the sensing process of an individual ${ }^{9}$.

Public perception of the existence of the Covid-19 virus is very decisive for the success of all parties in overcoming and preventing the spread of this virus, the perception of distrust of the existence of Covid-19 can have an impact on the neglect of health protocols in the community, a set of perceptions of trust in the existence of Covid-19 and its impact on health will create a caring attitude towards health protocols, furthermore it will participate in campaigning for health protocols to prevent the spread of the Covid-19 virus.

The impact of individual perceptions on the environment is also inseparable from the influence of the perceived identity of the individual, if that perception arises from the upper community, or community leaders, it will have a major influence on the way other people perceive the object that is perceived $^{10}$.

Likewise, if the perception of the existence of the Covid-19 virus is perceived by religious figures, then it can be ascertained that the religious environment or the people under it will cling to the perceptions of the character. Religious figures are an important part of society's elements that can educate the public about

\footnotetext{
${ }^{8}$ Sondang Siagian, Teori Motivasi dan Aplikasinya, (Jakarta: Rineka Cipta, 1995), 101-105.

${ }^{9}$ Bimo Walgito, Psikologi Umum, (Yogyakarta: Andi Offset, ) 88

${ }^{10}$ Miftah Thoha, Perilaku Organisasi, Konsep dan Aplikasinya, (Jakarta: PT. Raja Grafindo Persada, 2008), 141-148.
}

the cirus of Covid-19, so the perceptions of religious figures regarding the existence of Covid-19 are very important because they also influence the perceptions of the people.

East Java itself is one of the provinces with a high rate of Covid-19 cases, as of February 15, 2021, the total number of Covid-19 cases reached 122 thousand cases, with a cure rate of 109 thousand ${ }^{11}$. The Indopol survey from 23-28 July 2020, stated that $16.2 \%$ of the people of East Java considered that the Covid-19 pandemic had been exaggerated by the government and the World Health Organization (WHO). This survey was conducted on 1000 male and female respondents over the age of 17 using the stratified random sampling method, with an error margin of approximately $3.2 \%$ and a confidence level of more than 95\% (Slovin).

Data from BNPB delivered by Doni Monardo during a meeting with members of the House of Representatives of Commission VIII in Senayan Jakarta on September 3, 2020, stated that around $29.20 \%$ of East Java people feel immune and cannot contract Covid-19, some observers believe that Hoax information on social media is related to the theory that Covid-19 is part of a conspiracy to encourage public perceptions to distrust the existence of Covid-19.

The role of all parties is very central in participating in helping make the public aware of the fact that Covid-19 is a pandemic fact that must be faced together, including the role of religious leaders in providing counseling or lecturing to people in their respective religions.

Public awareness of the fact that Covid-19 is real must start from perceptions that are built through sensing, driven by an environment with the same perception, so as to create a communal perception in the community. Within the scope of the religious community, the perception of religious leaders is one of the important keys that can

\footnotetext{
${ }^{11}$ Data BNPB.
} 
influence the perceptions of the people. So this research is very interesting to do, in order to clearly know the perceptions of Confucian and Hindu religious figures in East Java regarding the Covid-19 pandemic.

\section{Research methods}

To obtain a complete description of the perceptions of religious communities in seeing the Covid-19 phenomenon in East Java, researchers used qualitative research methods, using data collection techniques through interviews.

In-depth interviews ${ }^{12}$ were conducted with Hindu and Confucian religious figures in East Java, including elements of the Confucian religion represented by Liem Tiong Yang as the Confucian clergy of Klenteng Boen Bio, Septiawan as elements of Confucian youth, Ongkie Setio Kuncoro as Chair of the Indonesian Confucian Religion Council (MATAKIN) ) East Java Province. Meanwhile, interviews with Hindus were carried out to several parties including Putu's brother as the representative of Hindu youth, Ketut Budhiarta as Secretary of the Parisadha Hindu Dharma (PHDI) East Java.

Interviews were conducted to answer the problems presented in the study, namely the perceptions of Confucian and Hindu religious leaders in East Java regarding Covid-19 academics. The process of qualitative research data analysis includes several things, firstly data reduction, this stage is the initial stage in the form of a process of separation, selection, simplification, abstractization, and transformation of crude data found in the field in a more refined form. Secondly, data presentation, this stage is a process of compiling a collection of information obtained from the field to then be presented in a clear, systematic, and logical manner so that it is easier to draw conclusions. Third, drawing conclusions and verification, in this

\footnotetext{
${ }^{12}$ Koenjtaraningrat, Metode- Metode Penelitian Masyarakat (Jakarta: Gramedia, 1994), 129
}

stage the researcher tries to understand, deepen and analyze the data presented so that until the conclusion is drawn from the research results, the conclusion is then verified the truth and validity ${ }^{13}$.

\section{Theoretical framework}

Covid-19 is a viral epidemic that has spread throughout the world, hundreds of countries in the world have been exposed to the Covid-19 pandemic ${ }^{14}$, various impacts are felt by the community, be it economic, social, religious and cultural. Public compliance with health protocols is a concrete step in preventing the spread of this pandemic from becoming more widespread, on the other hand the government is seeking vaccinations to increase the body's immunity against this virus attack.

Indonesia itself is struggling in dealing with the Covid-19 pandemic, the efforts of the government alone are not sufficient to overcome this virus attack, the role of all parties is needed, to participate in taking joint steps in overcoming and breaking the chain of Covid-19 transmission. The role of religious figures is very important in building people's awareness of the dangers of Covid-19 transmission.

One of the efforts is to build a common perception in the public that this pandemic really exists and is dangerous for humans. Perception is the experience that individuals get about an object or event, or the relationships obtained by inferring information and interpreting messages through sensory cues and supported by the influence of relevant past experiences and organized to provide a structured and meaningful picture for the individual ${ }^{15}$.

\footnotetext{
${ }^{13}$ Hardani, dkk, Metode Penelitian Kualitatif dan Kuantitatif, (Yogyakarta: Pustaka Ilmu Group, 2020), 164.

${ }^{14}$ Froma Walsh, "Loss and Resilience in the Time of COVID-19; Meaning Making, Hope, and

Transcendence, Family Process, Vol. 59 No. 3, 898.

${ }^{15}$ Alex Sobur, Psikologi Umum dalam LIntas

Sejarah, (Bandung: Pustaka Setia, 2013), 445.
} 
The term perception is usually used to express the experiences we have as part of an organized series of sense experiences developed in such a way that we are aware of our surroundings, including being aware of our own entities ${ }^{16}$.

Liliweri Alo in his book Interpersonal Communication mentions 3 processes that must be passed in forming perceptions, including stimulus or stimulation, registration and interpretation. From this process, a self-image emerges which is hereinafter referred to as perception $^{17}$.

In the context of definition, a religious figure is defined as an individual who has the knowledge of Religion and has the capacity for good morals ${ }^{18}$. There are also those who interpret religious figures as individual figures who carry out da'wahda'wah or spread the teachings of the goodness of Religion, both oral and written, both within the organizational and public sphere $^{19}$.

At the community level, religious leaders are role models for people in their religion, this is because religious leaders have advantages in both the fields of Religion, morality, or in other matters that are considered sacred by their followers. Thus the purpose of the title in this paper is to see the socio-religious perceptions of Confucian and Hindu religious figures in seeing the Covid-19 phenomenon in East Java, Covid-19 as a perceived object, then these perceptions are interpreted religiously.

\section{Discussion}

\footnotetext{
16 Abdul Rahman Saleh, Psikologi; Suatu Pengantar Dalam Prespektif Islam, (Jakarta: Kencana, 2004), 110.

${ }^{17}$ Liliweri Alo, Komunikasi Antar Personal, (Jakarta" PPrenada Media, Gorup, 2015), 169-174.

${ }^{18}$ Saiful Akhyar Lubis, Konseling Islami Kyai dan Pesantren, (Yogyakarta: eLSAQ Press, 2007), 169

${ }^{19}$ Ali Aziz, Ilmu Dakwah, (Jakarta: Kencana, 2004), 75 .
}

As is well known, Covid-19 has an impact on all aspects of life, including the social, educational, economic, cultural, political, security and religious fields ${ }^{20}$. Influences in the field of education, such as research conducted by Syarifah Hikmah Jamil with the theme "The Influence of Online Learning on Student Learning Interests during the Covid-19 Pandemic," from this research the findings show that attitudes of internet use, perceptions, experiences, financial conditions have a significant effect on interest ${ }^{21}$. student learning. Meanwhile, the ability to study independently does not have a significant effect. Then the research conducted by Rozqon Halal Syah Aji, with the title research on the Impact of Covid-19 on Education in Indonesia; School, Skills, and the Learning Process, from the results of the field study found that the pandemic was a difficult time in the world of education, the online learning process had to be carried out without careful preparation, the provision of adequate internet facilities and even some students who did not have it. devices for conducting distance education, the conditions of online learning also have an impact on students' psychology and reduce the quality of students, it is necessary to collaborate with all parties to find the best solutions to increase the effectiveness of online learning during the Covid-19 pandemic $^{22}$.

In the economic field, Sarip et al's research entitled "The Impact of Covid-19 on the Community Economy and Village Development", from the results of this study

\footnotetext{
${ }^{20}$ Kowalczyk, O., Roszkowski, K., Montane, X., Pawliszak, W., Tylkowski, B., \& Bajek, A. (2020). Religion and Faith Perception in a Pandemic of COVID-19. Journal of Religion and Health, 59(6), 2671-2677.

${ }^{21}$ Syarifah Hikmah Jamil, "Pengaruh Pembelajaran Daring Terhadap Minat Belajar Mahasiswa Pada Masa Pandemic Covid-19", Jurnal BAJ; Behavioral Accounting Journal, Vol. 3 No. 1 2020, 37-46

${ }^{22}$ Rizqon Halal Syah Aaji, "Dampak Covid-19 pada Pendidikan di Indonesia; Sekolah, Keterampilan, dan Proses Pembelajaran", Salam; Jurnal Sosial dan Budaya Syar'I, Vol. 7 No. 5 2020, 395-402
} 
found the fact that Covid-19 has affected the Indonesian economy in general, this can be seen from the structure of the State Budget and economic conditions that experienced a contraction, at the village level Covid-19 also had a significant impact on society in the economic field ${ }^{23}$. Furthermore, there is Ririn Noviyanti Putri's research entitled "The Impact of Covid -19 on the Economy in Indonesia", which results in findings that the Covid-19 outbreak has caused economic inflation in Indonesia, one of which is marked by an increase in domestic unemployment, therefore the government must take appropriate and efficient steps to overcome the bigger economic impact ${ }^{24}$. In the field of religion and culture, adaptation to the prevention of Covid-19 by implementing social distancing or physical distancing, either directly or indirectly, has affected patterns of religious practice or religious ceremonies ${ }^{25}$.

From here the religious community also experienced changes in the way of worship, including by not holding largescale religious traditions. In terms of worshiping Islam, for example due to maintaining distance and to reduce touch between individuals, after praying it is recommended not to do shaking greetings after prayer, this is done to reduce the transmission of cases of Covid-19, as well as the implementation of Eid and Eid. Adha which is carried out simply to reduce the spread of the Covid-19 outbreak ${ }^{26}$.

Likewise with other religious upper councils, which felt the impact of the Covid

\footnotetext{
${ }^{23}$ Sarip, dkk, "Dampak Covid-19 Terhadap Perekonomian Masyarakat dan Pembangunan Desa", Al Mustashfa; Jurnal Penelitian Hukum Ekonomi Islam, Vol. 5 No. 1 2020, 10-21.

${ }^{24}$ Ririn Noviyanti Putri, "Dampak Covid-19 terhadap Perekonomian di Indonesia", Jurnal Ekonomis; Journal of Economics and Business, Vol. 4 No. 2 2020, 384-388.

${ }^{25}$ Hasse Juba' "Beradptasi dengan Bencana; Strategi Beribadah Umat Islam dan Kristen di Tengah Pandemi", Jurnal Religious, Vol. 5 No. 1 2021, 2-14. ${ }^{26}$ Majalah FORUM, Edisi 01, 2020, FKUB Provinsi Jawa Timur.
}

19 pandemic in real terms, Pdt. Simon from the Fellowship of the Indonesian Churches (PGI) for the East Java region said that PGI had conveyed the technique of worshiping at home, for the celebration of white Thursday, big Friday, Easter and others ${ }^{27}$.

In essence, the Covid-19 pandemic is a fact whose impact can be felt by all elements of society, including the impact on social, economic, cultural and religious patterns of life. However, even though the impact has actually been felt by the community, there are still some people who do not believe in the existence of Covid-19 as a health threat, some argue that Covid-19 is a conspiracy deliberately made by certain groups to take advantage of this incident.

Even so, most people believe that covid-19 is a real virus outbreak, it can have a negative impact on health so that it needs to be handled specifically by the government in collaboration with all people by implementing recommended protocols to prevent the spread of covid- 19 .

How then will religious figures see the covid-19 phenomenon? The writer will conduct an in-depth study to see the covid19 response, to focus on the study, the author will limit the object with a focus on Hindu and Confucian religious figures in East Java. As we already know that Covid-19 has an impact on the patterns of worship of Hindus and Confucians, the implementation of health protocols in places of worship is strictly enforced. Experts argue that the Covid-19 pandemic is a condition in which social order has changed so that people (religious communities) also face by changing their behavior, including the issue of worship ${ }^{28}$.

The fact that the impact of covid-19 is in line with the opinion of the Confucian youth in responding to the existence of

\footnotetext{
${ }^{27}$ Ibid, 10.

${ }^{28}$ Hasse Juba' "Beradptasi dengan Bencana; Strategi Beribadah Umat Islam dan Kristen di Tengah Pandemi”, Jurnal Religious, Vol. 5 No. 1 2021, 2-14.
} 
covid-19, according to Surya Dewangga Putra $^{29}$, that the Covid-19 pandemic has had many impacts on various sectors, economic, social, cultural, including having an impact on religious patterns and procedures. religion in the Confucian community. The implementation of worship by using health protocols is a new thing that must be adapted by the Confucians, even in the implementation of religious holiday traditions which are massive and involve many masses, must be eliminated or carried out simply, to reduce the wider spread of Covid-19.

On several occasions, the government has always reminded that mass crowds involving many people in the implementation of religious traditions or other social activities have great potential to expand the spread of Covid-19 in the regions, because the government prohibits activities that involve many people, including traditional activities. religious.

Putu Bagus ${ }^{30}$, a Hindu youth said that many victims have fallen due to the Covid19 pandemic, all parties need to work together to fight this corona virus, given its real existence and has claimed many lives in the community, various policies that have been decided by the government must we support together, including implementing strict health protocols.

The death of hundreds of health workers as the vanguard in the eradication of Covid-19 is clear evidence that Covid-19 is a virus outbreak that threatens human life globally. Septiawan ${ }^{31}$, a young Confucian youth, said that this corona is real, there have been many health workers who have fallen because of fighting in the front of the eradication of Covid-19. In addition, many Covid-19 survivors have given testimonies of their experiences as individuals who have been exposed to Covid-19.

The belief in the existence of Covid19 as a real virus in society was also conveyed by Mr. Yudi, a Confucian religious leader in Pasuruan City, he said that Covid-19 indirectly affected the worship practices of Confucians in the city of Pasuruan. Large-scale religious celebrations were abolished, while daily worship activities and important observances of the Confucian religion were carried out strictly in compliance with health protocols. Furthermore, it was also conveyed that when there were Confucians who died not because of Covid-19, the place where the body was buried looked lonely, not as busy as usual, this is one proof that the Confucians feel the need to guard themselves by staying at home so as not to be exposed corona virus. ${ }^{32}$

Xs. Budi Tanuwibowo, as the general chairman of the Supreme Council for Indonesian Confucian Religion (MATAKIN), previously issued an appeal for the Confucians to carry out all their worship at home, especially ahead of the implementation of Confucian religious holidays such as Qingming, Matakin's anniversary, shenming holidays and routine worship. held in the temples ${ }^{33}$.

East Java Hindu figure, Mr. Budhiarta, stated that in general, Hindus strongly believe in the existence of Covid19 , this is a real threat to humans that must be resolved together. The government as Guru Wisesa deserves to be guided by all the policies it makes, according to Budhiarta this is important to do so that the threat of Covid19 can be countered by a movement in harmony, not making individual policies so that they do not coordinate well.

\footnotetext{
${ }^{32}$ Wawancara dengan Yudi, Tokoh Agama Konghucu kota Pasuruan

${ }^{33}$ Majalah FORUM; Edisi 01, 2020, Forum

Kerukunan Umat Beragama Provinsi Jawa Timur, hal 13.
}

\footnotetext{
${ }^{29}$ Wawancara dengan Surya Dewangga Putra, Pemuda Konghucu.

${ }^{30}$ Wawancara dengan Putu Bagus, Pemuda Hindu Jawa Timur.

${ }^{31}$ Wawancara dengan Septiawan, Pemuda Agama Konghucu Jawa Timur
} 
In line with this, an appeal was also conveyed by the central PHDI management, Nyoman Suarthanu representing Hindu religious leaders said that for Hindus to increase their faith more by doing worship and meditation at home, besides that it was also conveyed so that we were more productive even though we had to work from home ${ }^{34}$.

Hindus believe that every occurrence of natural disasters that occurs is due to an imbalance or disharmony in the universe, which can occur due to human behavior in treating nature. This is as stated in the tri hita karana, which is the philosophy of tough life.

This philosophy has a concept that can preserve cultural and environmental diversity in the midst of globalization and homogenization. Basically, the essence of the tri hita karana teachings emphasizes the three relationships of humans in life in this world. The three relationships include relationships with fellow humans, relationships with the natural surroundings, and relationships with God which are interrelated with one another. Every relationship has a life style of respecting other aspects around it. The principle of implementation must be balanced, in harmony with one another. When balance is reached, humans will live by avoiding all bad actions. His life will be balanced, serene, and peaceful.

The basic essence of Tri Hita Karana implies that the three causes of welfare are rooted in the harmonious relationship between humans and their Gods, humans and their natural environment, and humans and each other. By applying this philosophy, it is hoped that it can replace a modern way of life that emphasizes individualism and materialism. Cultivating Tri Hita Karana will

\footnotetext{
${ }^{34}$ Majalah FORUM; Edisi 01, 2020, Forum Kerukunan Umat Beragama Provinsi Jawa Timur, hal 12.
}

be able to eradicate the views that encourage consumerism, conflict and turmoil ${ }^{35}$.

Starting from this understanding, that Covid-19 is evidence of an indication of disharmony between the three things, therefore Hindus before the implementation of Nyepi, simultaneously in Indonesia carry out the Tawur Kesongo ceremony, which is a ceremony that must be performed to return to harmony with nature, This is one of the efforts made by Hindus so that a harmonious relationship with nature can run well again, so that the Covid-19 virus can be handled and not cause many victims ${ }^{36}$.

If you look at the opinions of various figures above, then both Confucianism and Hinduism believe in the existence of Covid19 with all the effects it has caused, there is no reason to deny the pandemic which has caused many victims from various circles, both ordinary people, health workers, religious figures, even political figures in Indonesia. Not to mention the economic impact that continues to be felt by the community, the government is focusing the state budget on dealing with the corona outbreak, the social assistance budget for the community continues to increase, as well as the health budget, for the fulfillment of domestic vaccines.

The application of health protocols in the rituals of worship is one of the solutions that are carried out and recommended by religious leaders, both Confucian and Hindu, this is in accordance with government directives so that the implementation of health protocols in various fields of religious activity is adhered to. Even some ceremonial religious festivals should be replaced with simpler ones to avoid large crowds.

\section{Closing}

Covid-19 is a real threat to human life, we can feel this together from the impact caused by its growing spread. Both

\footnotetext{
${ }^{35}$ Wawancara dengan Budhiarta, PHDI Jawa Timur.

${ }^{36}$ Wawancara dengan Budhiarta, PHDI Jawa Timur.
} 
Confucians and Hindus in East Java believe that the existence of Covid-19 is a serious problem that is currently being faced by society. The government, as a policy maker, provides a variety of rules to be obeyed together, so that the spread and impact of Covid-19 can be resolved immediately. Therefore Hindu and Confucian leaders appealed to their followers to adhere to health protocols, as recommended by the government.

\section{Bibliography}

Aji, Rizqon Halal Syah, "Dampak Covid-19 pada Pendidikan di Indonesia; Sekolah, Keterampilan, dan Proses Pembelajaran", Salam; Jurnal Sosial dan Budaya Syar'I, Vol. 7 No. 5 2020.

Alo, Liliweri, Komunikasi Antar Personal, Jakarta; Prenada Media, Gorup, 2015.

Aziz, Ali, Ilmu Dakwah, Jakarta: Kencana, 2004.

Badan Pusat Statistik (BPS).

Baig, A. M. Updates on What ACS Reported: Emerging Evidences of COVID-19 with Nervous System Involvement. ACS Chemical Neuroscience, 11(9), 2021.

Data BNPB.

Froma Walsh, "Loss and Resilience in the Time of COVID-19; Meaning Making, Hope, and Transcendence, Family Process, Vol. 59 No. 3.

Hadiwardoyo, "Kerugian Ekonomi Nasional Akibat Pandemi Covid-19", Journal of Business \& Entrepreneurship, 2(2), 2020.

Hanoatubun, "Dampak Covid-19 Terhadap Perekonomian Indonesia", Journal of Education, Psychology and Counseling, 2(1), 2020.

Hardani, dkk, Metode Penelitian Kualitatif dan Kuantitatif, Yogyakarta: Pustaka Ilmu Group, 2020.

Jamil, Syarifah Hikmah, "Pengaruh Pembelajaran Daring Terhadap Minat Belajar Mahasiswa Pada Masa Pandemic Covid-19", Jurnal BAJ;
Behavioral Accounting Journal, Vol. 3 No. 12020.

Juba', Hasse "Beradptasi dengan Bencana; Strategi Beribadah Umat Islam dan Kristen di Tengah Pandemi", Jurnal Religious, Vol. 5 No. 12021.

Kowalczyk, O., Roszkowski, K., Montane, X., Pawliszak, W., Tylkowski, B., \& Bajek, A. (2020). Religion and Faith Perception in a Pandemic of COVID19. Journal of Religion and Health, 59(6),

Koenjtaraningrat, Metode- Metode Penelitian Masyarakat Jakarta: Gramedia, 1994.

Loey, M., Manogaran, G., Taha, M. H. N., \& Khalifa, N. E. M. A hybrid deep transfer learning model with machine learning methods for face mask detection in the era of the COVID-19 pandemic. Measurement: 2021.

Lubis, Saiful Akhyar, Konseling Islami Kyai dan Pesantren, Yogyakarta: eLSAQ Press, 2007.

Majalah FORUM, Edisi 01, 2020, FKUB Provinsi Jawa Timur.

Moulahoum, H., Ghorbanizamani, F., Zihnioglu, F., Turhan, K., \& Timur, S. How should diagnostic kits development adapt quickly in COVID 19-like pandemic models? Pros and cons of sensory platforms used in COVID-19 sensing. Talanta, 2021.

Putri, Ririn Noviyanti, "Dampak Covid-19 terhadap Perekonomian di Indonesia", Jurnal Ekonomis; Journal of Economics and Business, Vol. 4 No. 22020.

Ren L-L, Wang Y-M, Wu Z-Q, Xiang Z-C, Guo $\mathrm{L}, \mathrm{Xu} \mathrm{T}$, Identification of $a$ novel coronavirus causing severe pneumonia in human: a descriptive study. Chin Med J. 2020.

Saleh, Abdul Rahman, Psikologi; Suatu Pengantar Dalam Prespektif Islam, Jakarta: Kencana, 2004.

Sarip, dkk, "Dampak Covid-19 Terhadap Perekonomian Masyarakat dan Pembangunan Desa", Al Mustashfa; 
Jurnal Penelitian Hukum Ekonomi Islam, Vol. 5 No. 12020.

Siagian, Sondang, Teori Motivasi dan Aplikasinya, Jakarta: Rineka Cipta, 1995.

Sobur, Alex, Psikologi Umum dalam LIntas Sejarah, Bandung: Pustaka Setia, 2013.

Thoha, Miftah, Perilaku Organisasi, Konsep dan Aplikasinya, Jakarta: PT. Raja Grafindo Persada, 2008.

Walgito, Bimo, Psikologi Umum, Yogyakarta: Ando Offset.

\section{Interview}

Wawancara dengan Surya Dewangga Putra, Pemuda Konghucu.

Wawancara dengan Putu Bagus, Pemuda Hindu Jawa Timur.

Wawancara dengan Septiawan, Pemuda Agama Konghucu Jawa Timur.

Wawancara dengan Yudi, Tokoh Agama Konghucu kota Pasuruan.

Wawancara dengan Budhiarta, PHDI Jawa Timur.

Wawancara dengan Budhiarta, PHDI Jawa Timur. 